\title{
Unusual case of severe arrhythmia developed after acute intoxication with tosylchloramide
}

\author{
Vincenzo Lariccia ${ }^{1 \dagger}$, Alessandra Moraca ${ }^{2 \dagger}$, Marco Marini ${ }^{2}$, Annamaria Assunta Nasti ${ }^{1}$, llaria Battistoni ${ }^{2}$, \\ Salvatore Amoroso ${ }^{1 *}$ and Gian Piero Perna ${ }^{2}$
}

\begin{abstract}
Background: Drugs not commonly considered to be cardioactive agents may cause prolongation of the QT interval with resultant torsades de pointes and ventricular fibrillation. This form of drug toxicity often causes cardiac arrest or sudden death.

Case presentation: After accidental ingestion of tosylchloramide a caucasian 77-year-old woman, with a family history of cardiovascular disease and hypertension, was admitted to the intensive care unit following episodes of torsades de pointes with a prolonged QT/QTc interval (640/542 ms). The patient received an implantable cardioverter-defibrillator, was discharged from the hospital with normal QT/QTc interval and did not experience additional ventricular arrhythmias during one year of follow-up.

Conclusion: This is the first report concerning an unusual case of torsades de pointes after accidental intoxication by ingestion of tosylchloramide. The pronounced impact of the oxidyzing agent tosylchloramide on the activity of some of the ion channels regulating the QT interval was identified as a probable cause of the arrhythmia.
\end{abstract}

Keywords: Tosylchloramide, Acute intoxication, Arrhythmia, Ventricular fibrillation, lon channels

\section{Background}

Because of its high activity against fungi and bacteria, tosylchloramide is a widely used disinfectant agent for common applications such household cleaning and swimming pool disinfection. Many case reports describing tosylchloramide intoxication have been already published in the past showing that the chronic exposure to this compound may cause hypersensitivity reactions, such as asthma [1,2], conjunctivitis [3], whereas toxic pneumonitis [4], cardiovascular collapse and myocardial damage may occur in acutely intoxicated patients [5]. Here we report the first case of a severe arrhythmia developed in the context of acute oral intoxication with tosylchloramide.

\section{Case presentation}

A 77-year-old woman presenting shoulder girdle pain was admitted to our hospital with suspected coronary

\footnotetext{
* Correspondence: s.amoroso@univpm.it

${ }^{\dagger}$ Equal contributors

'Department of "Biomedical Sciences and Public Health, University

"Politecnica delle Marche", Ancona, Italy

Full list of author information is available at the end of the article
}

syndrome. She had a history of hypertension; treated since 5 years with Perindopril (5 mg once daily) and a family history of cardiovascular disease. Few hours after the admission at the Emergency Room (ER) the patient experienced a cardiac arrest due to a "Torsade de Pointes" (TdP) degenerated into ventricular fibrillation which required DC shock (200 J), as documented by electrocardiogram (ECG) (Figure 1). After specific questioning for drug intake, the patient revealed She had accidentally (non-intentionally) ingested an entire sachet of Euclorina (containing $2.5 \mathrm{~g}$ of tosylchloramide) between 5 and 6 hours before TdP.

Surface ECG on admission in ER showed sinus rhythm with pre-existing left bundle branch block (LBBB). Serum potassium was in slightly lower normal range (3.3 mEq/l, before $3.8 \mathrm{mEq} / \mathrm{l})$, while other haematological parameters were in their respective reference intervals (data not shown). On admission to the cardiology Intensive Care Unit (ICU) the ECG disclosed sinus bradycardia $(55 \mathrm{bpm})$ with significant alteration in the QT interval $(\mathrm{QT} / \mathrm{QTc}=640 / 543 \mathrm{msec}$; Figure 2) that was significantly prolonged over a 24-hour period. Thereafter the patient underwent an echocardiography 


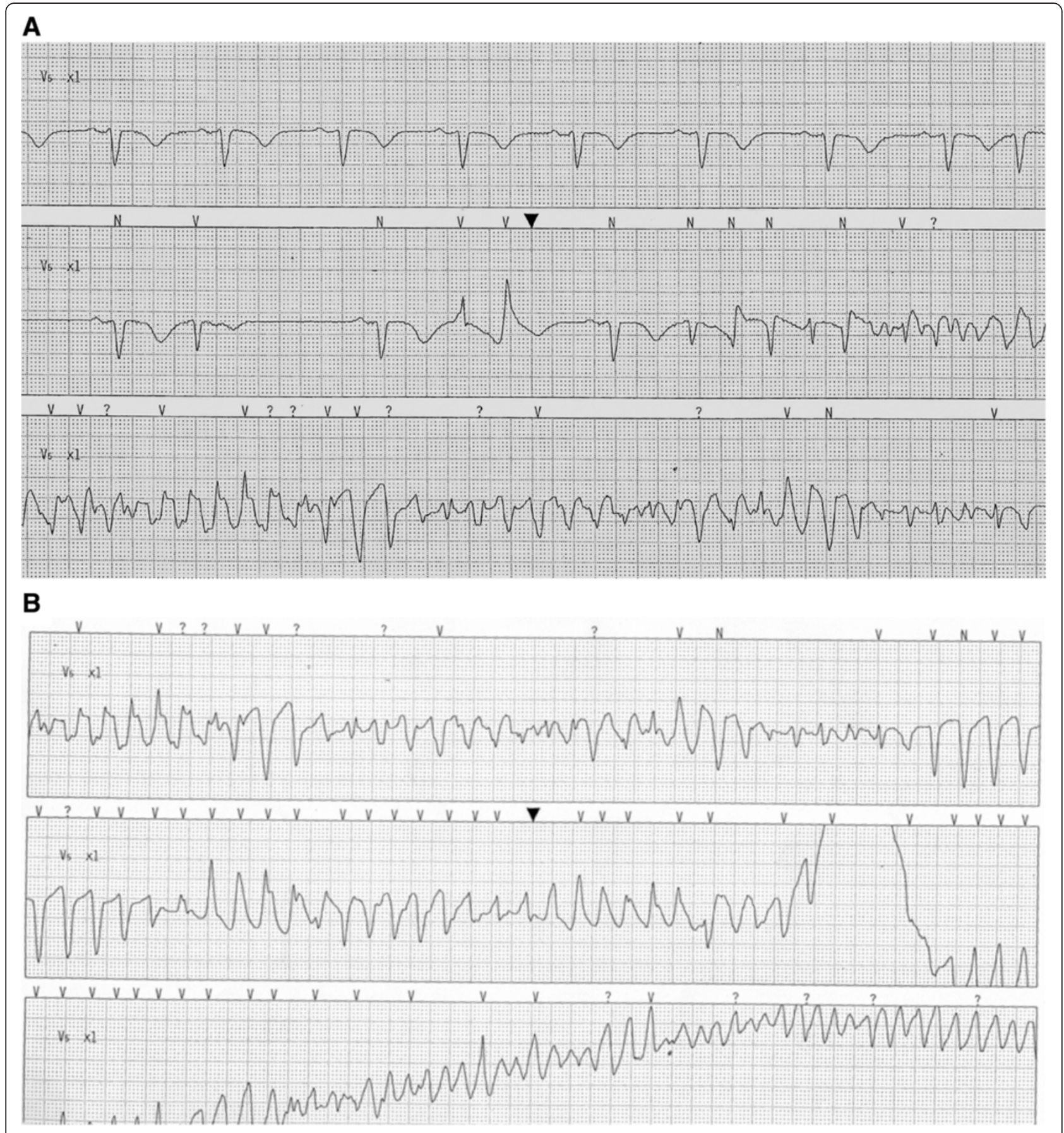

Figure 1 TDP with fast degeneration into Ventricular Fibrillation. The ECG-strip pre-TDP (Figure1A) shows a QT interval of 640 msec (QTc is $542 \mathrm{msec}$ ).

that revealed concentric left ventricle hypertrophy with a mild reduction in global systolic function $(\mathrm{LVEF}=50 \%)$ due to LBBB-induced dyssynergy of the interventricular anterior septum wall.

The middle left anterior descending coronary artery (LAD) had a non-significant stenosis $(<50 \%)$ as revealed by coronary angiography and IVUS control (Figure 3). A not significant stenosis was detected in a non-dominant right coronary artery (Figure 3). According to the criteria defined in Thygesen et al. [6], myocardial infarction was excluded for the following reasons: a) no symptoms or electrocardiographic changes were detected; b) the peak 


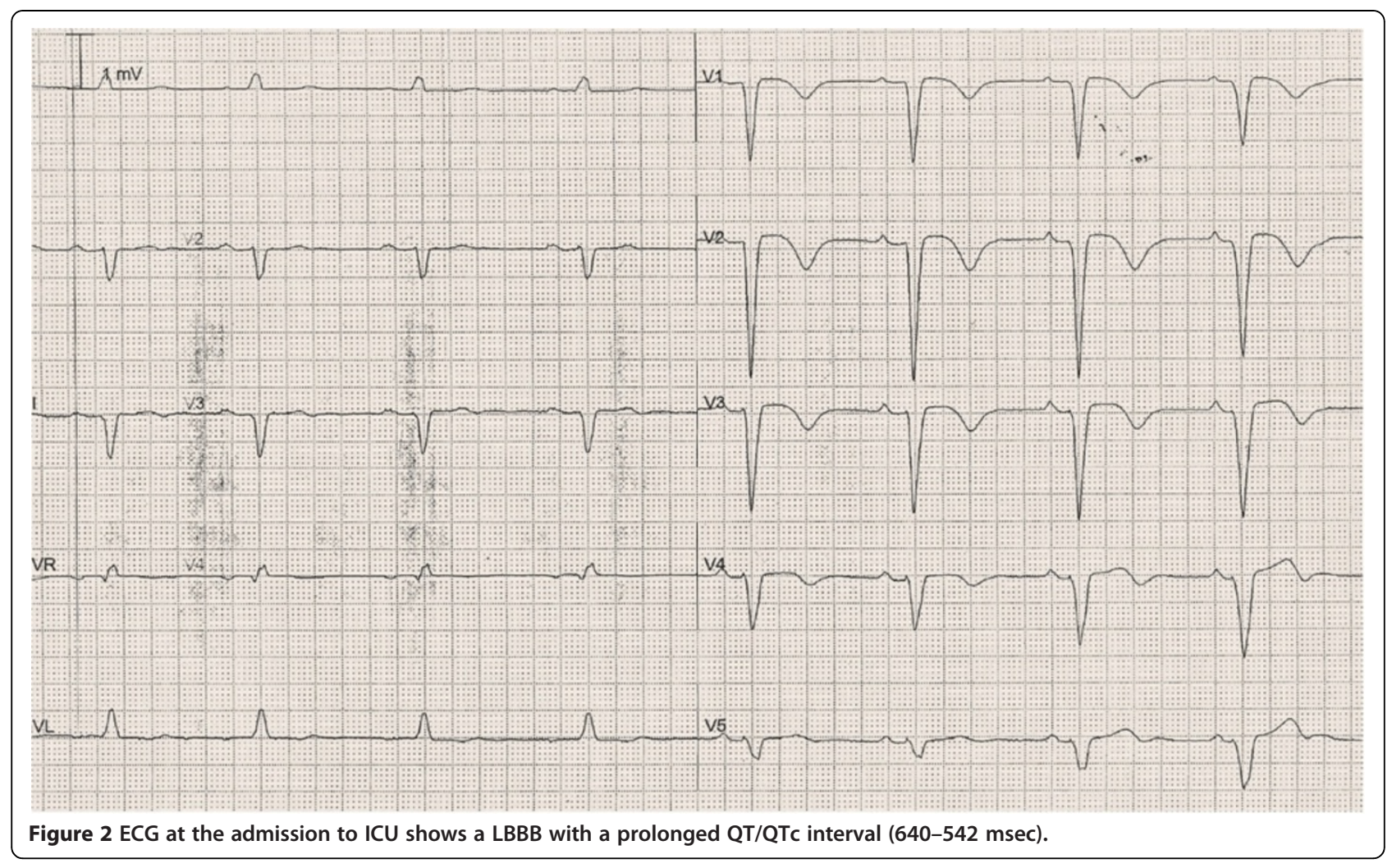

CK-MB level was $8.1 \mathrm{ng} / \mathrm{ml}$ (the normal reference value in our laboratory is $<5 \mathrm{ng} / \mathrm{ml}$ ) only after $6 \mathrm{~h}$ from DC shock, and normalized $(3.2 \mathrm{ng} / \mathrm{ml})$ within the following $6 \mathrm{~h} ; \mathrm{c}$ ) the peak Troponin I level was $0.32 \mathrm{ng} / \mathrm{ml}$ (the normal reference value in our laboratory is $<0.08 \mathrm{ng} / \mathrm{ml}$ ) $6 \mathrm{~h}$ after DC shock, and normalized $(0.06 \mathrm{ng} / \mathrm{ml}) 6 \mathrm{~h}$ later. No signs of liver or kidney derangement were observed (data not shown).

The patient was discharged 7 days after admission, following the placement of an implantable cardioverterdefibrillator (ICD); the ECG at discharge showed a LBBB with a normal QT interval $(\mathrm{QT} / \mathrm{QTc}=400 / 430 \mathrm{msec}$; Figure 4). After 12 and 24 months of follow-up She has been clinically stable, no shock detected at ICD registration and her QT interval was normal (Figure 5).

\section{Discussion}

The occurrence of TdP in our patient after tosylchloramide ingestion can be explained considering that this compound acts as a strong oxidant of methionines and cysteines residues in proteins [7]. The activity of some of the ion channels regulating the duration of the QT interval is, indeed, strongly influenced by oxydation of critical methionine residues in channel proteins. In particular, voltage-dependent inactivation of $\mathrm{Na}_{\mathrm{V}}$ channels is significantly slowed down when methionine residues located in the so called IMF domain, which is responsible for voltage-dependent channel inactivation, are oxydized [8]. Consistently, tosylchloramide, which has a strong preference in oxydizing methionine residues [9], is one of the most powerful oxydants affecting $\mathrm{Na}_{\mathrm{V}}$ channel inactivation $[9,10]$ and it has been used as a pharmacological tool to abolish voltage-dependent inactivation in studies aiming to determine its contribution in the activity of specific cardiovascular drugs [11]. Tosylchloramideinduced slowing of $\mathrm{Na}_{\mathrm{V}}$ channel inactivation is a quite general phenomenon being observed in the brain, muscle and, importantly, cardiac isoform of these channels [8]. Oxydant-induced impairment of $\mathrm{Na}_{\mathrm{V}}$ voltage-dependent inactivation may per se explain the appearance of TdP in our patient intoxicated with tosylchloramide since it causes a marked increase in persistent $\mathrm{I}_{\mathrm{Na}}\left(\mathrm{I}_{\mathrm{Na}} \mathrm{P}\right)$ $[12,13]$, the inactivation-resistant $\mathrm{Na}^{+}$current which persists in the presence of prolonged membrane depolarization [14]. An increase in $\mathrm{I}_{\mathrm{Na}} \mathrm{P}$ is, indeed, a well documented mechanism of QT prolongation and arrhythmogenesis and a potentailly relevant target for treatment and prevention of arrhythmias [15,16]. In addition, an increase in $\mathrm{I}_{\mathrm{Na}} \mathrm{P}$ is considered responsible for arrhythmogenesis in patients affected with the LQT3 syndrome which bear specific mutations in the $\mathrm{Na}_{\mathrm{V}} 1.5$ channel gene [17-19]. Confirming the involvement of $\mathrm{I}_{\mathrm{Na}} \mathrm{P}$ in oxydant-induced arrhythmogenesis, the $\mathrm{I}_{\mathrm{Na}} \mathrm{P}$ blocker ranolazine was effective in preventing QT 


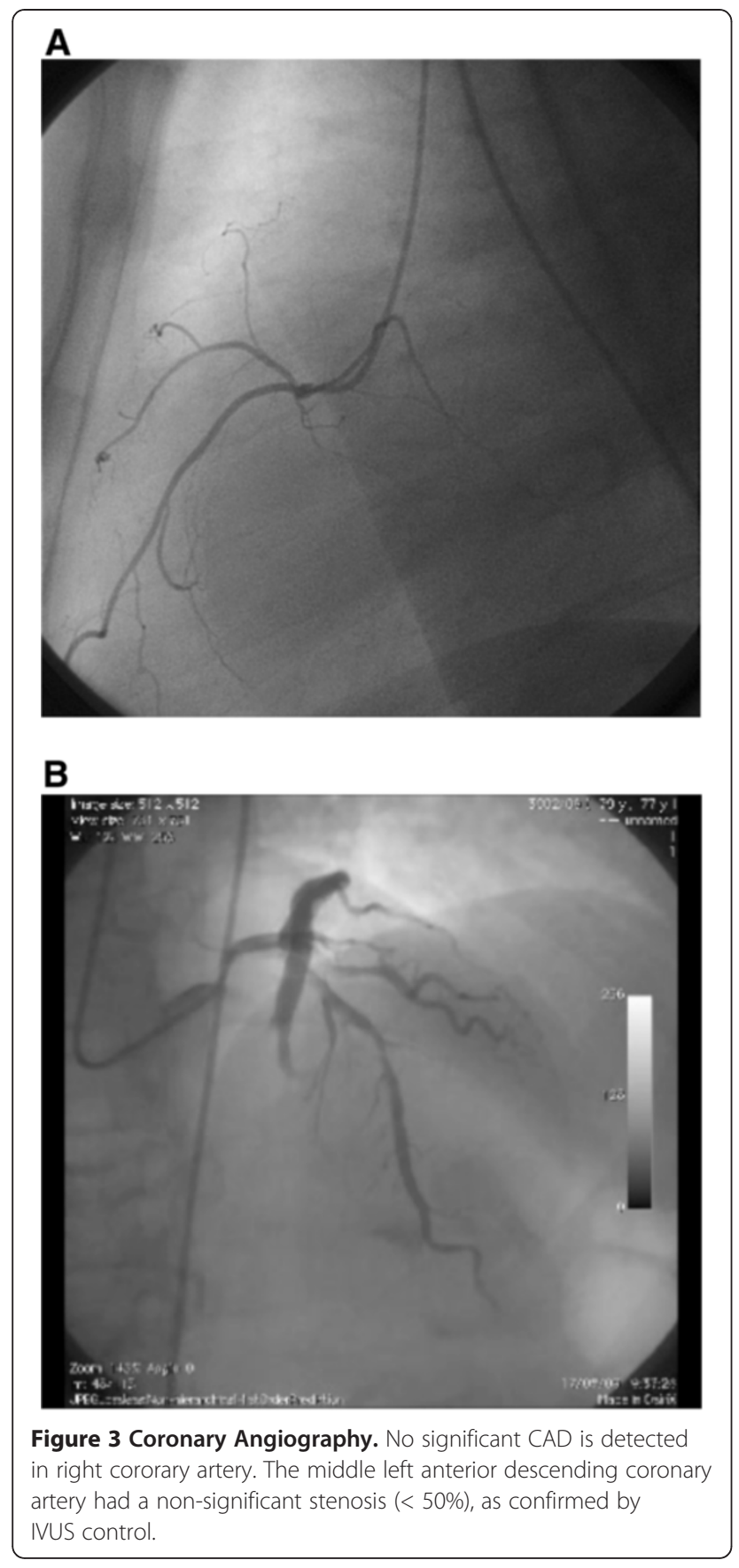

prolongation and early afterdepolarzations induced by the strong oxydant agent $\mathrm{H}_{2} \mathrm{O}_{2}$ in cultured guinea pig cardiomyocytes [13]. Therefore, it is tempting to speculate that, in our patient, tosylchloramide exposure recapitulated the pathophysiological mechanism of cardiac arrhythmia in LQT3 patients.

hERG is another oxydation-sensitive ion channel that could have been involved in the genesis of $\mathrm{TdP}$ in our patient. hERG is the main $\mathrm{K}^{+}$current responsible for rapid repolarization of cardiac myocytes in phase III of cardiac action potential [20] and its loss of function is one of the best characterized mechanisms of druginduced or congenital LQT syndrome [21]. Specifically, mutations causing either loss of function or alterations in trafficking of hERG channels are responsible for the LQT2 syndrome [22,23] whereas mutations in MiRP1, an accessory subunit that coassembles with hERG, have been found in LQT6 patients [24]. Intriguingly, by oxydizing critical methionine residues, tosylchloramide causes an almost complete loss of hERG channel activity in vitro [25] thus reproducing the effect of drugs or mutations known to cause TdP. Therefore, it is likely that hERG channel blockade could have played a role in the appearance of $\mathrm{TdP}$ in our patient.

Finally, it is worth to remind that several oxydants, including tosylchloramide, may also increase the activity of L-type voltage-gated $\mathrm{Ca}^{2+}$ channels (VGCC), even though, in this case, the specific inolvement of methionine residues has not been demonstrated [26,27]. By increasing $\mathrm{Ca}^{2+}$ influx through L-type VGCC, tosylchloramide is expected to prolong the plateau phase of cardiac action potential thus delaying cardiomyocyte repolarization and promoting the appearance of TdP. Intriguingly, an increase in L-type VGCC activity represents the mechanistic base of arrhythmias in LQT8 patients [28-30] bearing the Timothy syndrome mutations which cause an impairment in voltage-dependent $\mathrm{Ca}_{V} 1.2$ channel inactivation [31].

\section{Conclusion}

Oxidative stress has been proposed as one of the upstream events provoking clinical relevant arrhythmic responses [32] and several drugs used in therapy exert antiarrhythmic effects in part via their antioxidative property [33,34]. Here we suggest that severe arrhythmia may occur in the form of TdP after massive exposure to the oxidizing agent tosylchloramide. In fact, tosylchloramide has a pronounced impact on the activity of some of the ion channels regulating the QT interval. Since our patient exhibited no evidence of QT interval alteration after 12 and 24 months of follow-up, this strongly suggests a causal role of tosylchloramide intoxication for the ECG abnormalities occurred during observation in the ICU. Therefore, a strict electrocardiographic monitoring is advised in patients intoxicated with this compound.

\section{Consent}

Written informed consent was obtained from the patient prior to publication of this case report and any accompanying images. A copy of the written consent is available for review by the Series Editor of this journal. 




Figure 4 ECG at hospital discharge. QT interval measures $400 \mathrm{msec}$, the QTc interval $430 \mathrm{msec}$.

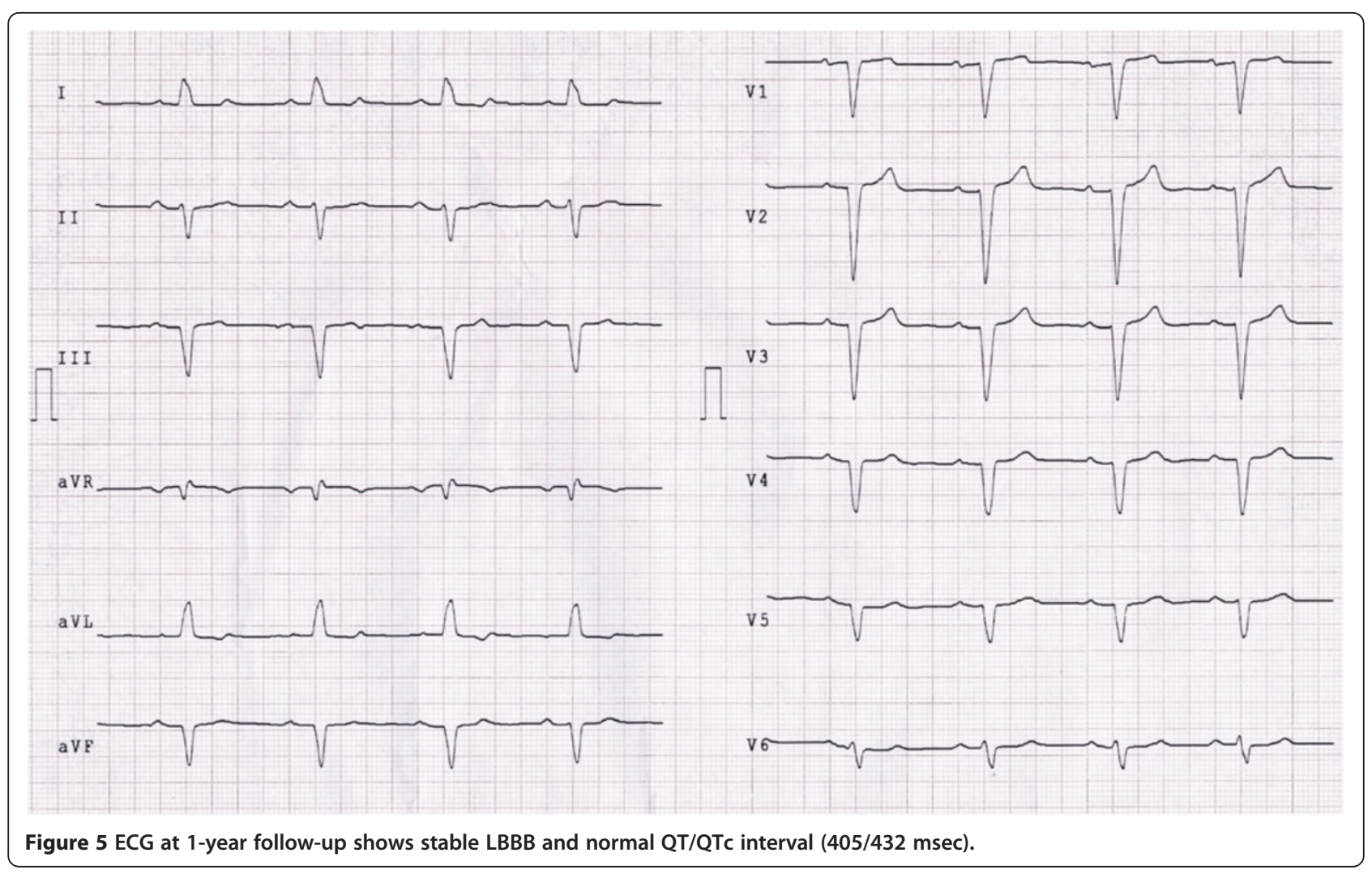




\section{Competing interest}

The authors declare that they have no competing interest.

\section{Authors' contributions}

AM identified and managed the case; GPP and SA analyzed the data, conceived of the study and helped to draft the manuscript; VL, MM, AAN and IB performed the literature search and wrote the article. All authors read and approved the final manuscript.

\section{Authors' information}

Salvatore Amoroso and Gian Piero Perna equally contributed as senior authors.

\section{Author details}

${ }^{1}$ Department of "Biomedical Sciences and Public Health, University "Politecnica delle Marche", Ancona, Italy. 'Department of Cardiology, Azienda Ospedaliero-Universitaria "Ospedali Riuniti di Ancona", Ancona, Italy.

Received: 4 September 2012 Accepted: 21 January 2013 Published: 24 January 2013

\section{References}

1. Blasco A, Joral A, Fuente R, Rodríguez M, García A, Domínguez A: Bronchial asthma due to sensitization to chloramine T. J Investig Allergol Clin Immunol 1992, 2:167-170.

2. Kujala VM, Reijula KE, Ruotsalainen EM, Heikkinen K: Occupational asthma due to chloramine-T solution. Respir Med 1995, 89:693-695.

3. Grant WM: Toxicology of the eye. Srpingfield: Charles C. Thomas; 1974.

4. Pascuzzi TA, Storrow AB: Mass casualties from acute inhalation of chloramine gas. Mil Med 1998, 163:102-104.

5. Gonzalez-Castro A, Holanda MS, Canas BS, Morlote JG, Minambres E, Prieto Solis JA: Myocardial damage after inhalation of chloramines. Eur J Emerg Med 2006, 13:108-110.

6. Thygesen K, Alpert JS, White HD: Universal definition of myocardial infarction. Eur Heart J 2007, 28:2525-2538.

7. Mihajlovic V, Cascone O, Biscoglio de Jiménez Bonino MJ: Oxidation of methionine residues in equine growth hormone by Chloramine-T. Int J Biochem 1993, 25:1189-1193.

8. Kassmann M, Hansel A, Leipold E, Birkenbeil J, Lu SQ, Hoshi T, Heinemann $\mathrm{SH}$ : Oxidation of multiple methionine residues impairs rapid sodium channel inactivation. Pflugers Arch 2008, 456:1085-1095

9. Wang GK: Irreversible modification of sodium channel inactivation in toad myelinated nerve fibres by the oxidant chloramine-T. J Physiol 1984, 346:127-141.

10. Quiñonez M, DiFranco M, González F: Involvement of methionine residues in the fast inactivation mechanism of the sodium current from toad skeletal muscle fibers. J Membr Biol 1999, 169:83-90.

11. Nawada T, Tanaka Y, Hisatome I, Sasaki N, Ohtahara A, Kotake H, Mashiba H, Sato R: Mechanism of inhibition of the sodium current by bepridil in guinea-pig isolated ventricular cells. Br J Pharmacol 1995, 116:1775-1780.

12. Niemann P, Schmidtmayer J, Ulbricht W: Chloramine-T effect on sodium conductance of neuroblastoma cells as studied by whole-cell clamp and single-channel analysis. Pflugers Arch 1991, 418:129-136.

13. Song Y, Shryock JC, Wagner S, Maier LS, Belardinelli L: Blocking late sodium current reduces hydrogen peroxide-induced arrhythmogenic activity and contractile dysfunction. J Pharmacol Exp Ther 2006, 318:214-222.

14. Maltsev VA, Sabbah HN, Higgins RS, Silverman N, Lesch M, Undrovinas Al: Novel, ultraslow inactivating sodium current in human ventricular cardiomyocytes. Circulation 1998, 98:2545-2552.

15. Hasenfuss G, Maier LS: Mechanism of action of the new anti-ischemia drug ranolazine. Clin Res Cardiol 2008, 97:222-226.

16. Undrovinas A, Maltsev VA: Late sodium current is a new therapeutic target to improve contractility and rhythm in failing heart. Cardiovasc Hematol Agents Med Chem 2008, 6:348-359.

17. Bennett PB, Yazawa K, Makita N, George AL Jr: Molecular mechanism for an inherited cardiac arrhythmia. Nature 1995, 376:683-685.

18. Christé $G$, Chahine $M$, Chevalier P, Pásek M: Changes in action potentials and intracellular ionic homeostasis in a ventricular cell model related to a persistent sodium current in SCN5A mutations underlying LQT3. Prog Biophys Mol Biol 2008, 96:281-293.
19. Tian XL, Yong SL, Wan X, Wu L, Chung MK, Tchou PJ: Mechanisms by which SCN5A mutation N1325S causes cardiac arrhythmias and sudden death in vivo. Cardiovasc Res 2004, 61:256-267.

20. Tseng GN: I(Kr): the hERG channel. J Mol Cell Cardiol 2001, 33:835-849.

21. Sanguinetti MC, Jiang C, Curran ME, Keating MT: A mechanistic link between an inherited and an acquired cardiac arrhythmia: HERG encodes the IKr potassium channel. Cell 1995, 81:299-307.

22. Curran ME, Splawski I, Timothy KW, Vincent GM, Green ED, Keating MT: A molecular basis for cardiac arrhythmia: HERG mutations cause long QT syndrome. Cell 1995, 80:795-803.

23. Chiang CE, Roden DM: The long QT syndromes: genetic basis and clinical implications. J Am Coll Cardiol 2000, 36:1-12.

24. Abbott GW, Sesti F, Splawski I, Buck ME, Lehmann MH, Timothy KW, Keating MT, Goldstein SA: MiRP1 forms IKr potassium channels with HERG and is associated with cardiac arrhythmia. Cell 1999, 97:175-187.

25. Su Z, Limberis J, Martin RL, Xu R, Kolbe K, Heinemann SH, Hoshi T, Cox BF, Gintant GA: Functional consequences of methionine oxidation of hERG potassium channels. Biochem Pharmacol 2007, 74:702-711.

26. Campbell DL, Stamler JS, Strauss HC: Redox modulation of L-type calcium channels in ferret ventricular myocytes. Dual mechanism regulation by nitric oxide and S-nitrosothiols. J Gen Physiol 1996, 108:277-293.

27. Yamaoka K, Yakehiro M, Yuki T, Fujii H, Seyama I: Effect of sulfhydryl reagents on the regulatory system of the L-type Ca channel in frog ventricular myocytes. Pflugers Arch 2000, 440:207-215.

28. Jacobs A, Knight BP, McDonald KT, Burke MC: Verapamil decreases ventricular tachyarrhythmias in a patient with Timothy syndrome (LQT8). Hear Rhythm 2006, 3:967-970.

29. Splawski I, Timothy KW, Sharpe LM, Decher N, Kumar P, Bloise R, Napolitano C, Schwartz PJ, Joseph RM, Condouris K, Tager-Flusberg H, Priori SG, Sanguinetti MC, Keating MT: Ca(V)1.2 calcium channel dysfunction causes a multisystem disorder including arrhythmia and autism. Cell 2004, 119:19-31.

30. Splawski I, Timothy KW, Decher N, Kumar P, Sachse FB, Beggs AH, Sanguinetti MC, Keating MT: Severe arrhythmia disorder caused by cardiac L-type calcium channel mutations. Proc Natl Acad Sci USA 2005, 102:8089-8096.

31. Barrett CF, Tsien RW: The Timothy syndrome mutation differentially affects voltage- and calcium-dependent inactivation of CaV1.2 L-type calcium channels. Proc Natl Acad Sci USA 2008, 105:2157-2162.

32. Jeong EM, Liu M, Sturdy M, Gao G, Varghese ST, Sovari AA, Dudley SC: Metabolic stress, reactive oxygen species, and arrhythmia. J Mol Cell Cardiol 2012, 52:454-463.

33. Liu T, Li G: Antioxidant interventions as novel preventive strategies for postoperative atrial fibrillation. Int J Cardiol 2010, 145:140-142.

34. Naccarelli GV, Lukas MA: Carvedilol's antiarrhythmic properties: therapeutic implications in patients with left ventricular dysfunction. Clin Cardiol 2005, 28:165-173.

doi:10.1186/2050-6511-14-8

Cite this article as: Lariccia et al:: Unusual case of severe arrhythmia developed after acute intoxication with tosylchloramide. BMC Pharmacology and Toxicology 2013 14:8.

\section{Submit your next manuscript to BioMed Central and take full advantage of:}

- Convenient online submission

- Thorough peer review

- No space constraints or color figure charges

- Immediate publication on acceptance

- Inclusion in PubMed, CAS, Scopus and Google Scholar

- Research which is freely available for redistribution 